\title{
Implant-associated ESBL-Klebsiella pneumonia producing small colony variant bone and joint infection in a healthy 40-year-old man
}

\author{
Cécile Ronde-Oustau, ${ }^{1}$ Sébastien Lustig, ${ }^{2,3,4}$ Céline Dupieux, ${ }^{3,4,5,6}$ Tristan Ferry, $^{3,4,6,7}$ \\ on behalf of the Lyon BJI Study group
}

\begin{abstract}
'Laboratoire de Bactériologie, Hôpitaux Universitaires de Strasbourg, Strasbourg, France ${ }^{2}$ Service de Chirurgie Orthopédique, Centre Albert Trillat, Hôpital de la CroixRousse, Hospices Civils de Lyon, Lyon, France ${ }^{3}$ Centre Interrégional de Référence des Infections Ostéoarticulaires complexes (CRIOAC Lyon), Hospices Civils de Lyon, Lyon, France

${ }^{4}$ Université Claude Bernard Lyon 1, Lyon, France Laboratoire de Bactériologie, Hôpital de la Croix-Rousse, Hospices Civils de Lyon, Lyon, France

${ }^{6}$ Centre International de Recherche en Infectiologie, CIRI, Inserm U1111, CNRS UMR5308, ENS de Lyon, UCBL1, Lyon, France ${ }^{7}$ Service de Maladies Infectieuses et Tropicales, Hôpital de la Croix-Rousse, Hospices Civils de Lyon, Lyon, France
\end{abstract}

\section{Correspondence to}

Dr Tristan Ferry, tristan.ferry@ univ-lyon $1 . f r$

Accepted 23 January 2017

\section{DESCRIPTION}

A 40-year-old man underwent a bifocal fracture of the left leg in Senegal. An intramedullar rod was implanted to obtain consolidation. At 7 months, the patient was admitted to our institution as the distal fracture had not consolidated (figure 1A). There was no clinical sign of infection. A 1-stage exchange of the rod was performed. No abscess or suspected tissue was detectable during the surgery. Systematic peroperative test of samples were performed, and revealed Klebsiella pneumonia producing extended-spectrum $\beta$-lactamase (ESBL), and some colonies expressed the small colony variant (SCV) phenotype in the culture (with the same antibiotic susceptibility), which was also identified to be $K$. pneumonia (figure $1 \mathrm{~B}$ and $\mathrm{C}$ ). An early new intervention was required due to local abscess formation, the rod was explanted, the tibia was immobilised with a cruro-pedal cast and negative pressure therapy on the skin defect was instaured. Peroperative bacteriology always showed $K$. pneumoniae in culture. Antibiotics with meropenem (6 g/day) and colimycine (colistimethate sodium, $6 \mathrm{MUI} /$ day) were started, and skin and soft tissue flap was performed to cover the exposed bone of the proximal tibia. At 3 months of antimicrobial therapy (no adverse event occurred), the fracture had consolidated as seen on the X-ray (figure $1 \mathrm{D}$ and $\mathrm{E}$ ) and the antibiotics were stopped. The outcome was favourable, and the patient is walking now without pain and without any sign of infection.

Enterobacteriaceae could be responsible for bone and joint infection (BJI), but are most of time responsible for acute postoperative or haematogenous infections. The SCV phenotype corresponds to a reversible switch of the metabolism of bacteria, leading to slow-growing forms that are associated with intracellular persistence and pin point colonies on blood agar. ${ }^{1}$ Most of the BJIs associated with the expression of the SCV phenotype are chronic implant-associated staphylococci BJI. ${ }^{1}{ }^{2}$ To the best of our knowledge this is the first case of $\mathrm{K}$. pneumonia SCV description, especially in a BJI. Gram-negative SCV are well described with Pseudomonas aeruginosa or Stenotrophomonas spp. in cystic fibrosis, but less is known in BJI. Sendi et al reported that Escherichia coli SCV could be detected on tissues and sonication fluid in patients with chronic prosthetic-joint infection. Biochemical reactions were modified in variants, but some were restored after passage on culture medium. This study concludes that with Gram-negative rods expressing the SCV phenotype, biochemical modifications lead to mis-identification or non-identification with routine bacteriological methods. ${ }^{3}$ A combination antimicrobial therapy is usually proposed to treat BJI due to multidrug-resistant pathogens, to avoid a relapse with acquisition of further resistance.
To cite: Ronde-Oustau C Lustig S, Dupieux C, et al. BMJ Case Rep Published online: [please include Day Month Year] doi:10.1136/ bcr-2016-217542
A

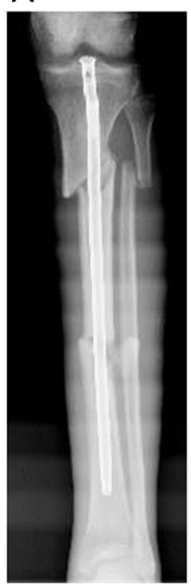

B

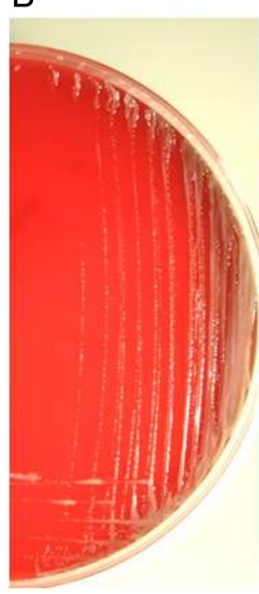

C
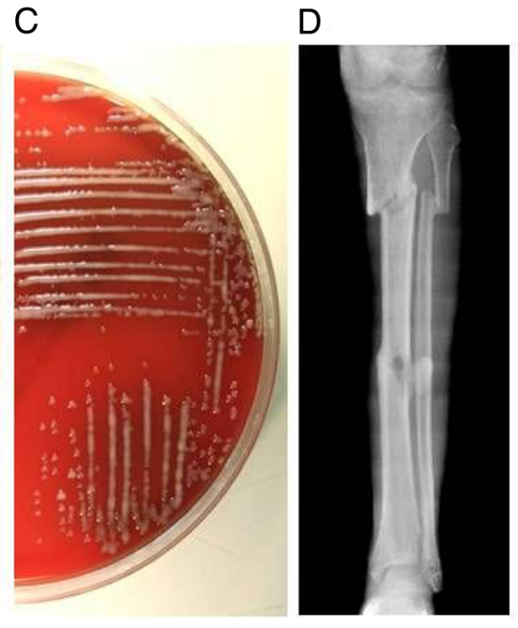

E

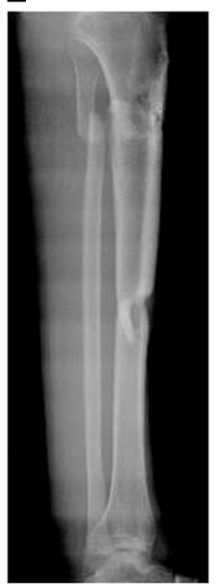

Figure 1 (A) X-ray of the tibia at admission, showing the unconsolidated bifocal fracture and the tibial nail; (B) Pinpoint colonies on blood agar of ESBL Klebsiella pneumonia from peroperative samples corresponding to the SCV phenotype; (C) Classical phenotype on blood agar of the ESBL $K$. Pneumonia from the same peroperative samples; (D) and (E) X-ray of the tibia (face and profile) 6 months after the end of the antimicrobial therapy showing consolidation, in a patient walking without any pain. ESBL, extended-spectrum $\beta$-lactamase; SCV, small colony variant. 


\section{Learning points}

- Klebsiella pneumonia could express the small colony variant (SCV) phenotype in patients with implant-associated bone and joint infection (BJI).

- Implant removal and a 3 months course of targeted antimicrobial therapy facilitate the cure of SCV in implant-associated BJI.

- Gram-negative SCV could express biochemical modifications that may lead to mis-identification or non-identification with routine bacteriological methods.

Acknowledgements Lyon Bone and Joint Infection Study Group: Coordinator: Tristan Ferry; Infectious Diseases Specialists: Tristan Ferry, Florent Valour, Thomas Perpoint, André Boibieux, François Biron, Patrick Miailhes, Florence Ader, Agathe Becker, Sandrine Roux, Claire Philit, Fatiha Daoud, Johanna Lippman, Evelyne Braun, Christian Chidiac, Yves Gillet, Laure Hees; Surgeons: Sébastien Lustig, Philippe Neyret, Yannick Herry, Romain Gaillard, Antoine Schneider, Michel-Henry Fessy, Anthony Viste, Philippe Chaudier, Romain Desmarchelier, Thibault Vermersch,
Sébastien Martres, Franck Trouillet, Cédric Barrey, Francesco Signorelli, Emmanuel Jouanneau, Timothée Jacquesson, Ali Mojallal, Fabien Boucher, Hristo Shipkov, Mehdi Ismail, Joseph Chateau; Microbiologists: Frederic Laurent, François Vandenesch, Jean-Philippe Rasigade, Céline Dupieux; Nuclear Medicine: Isabelle Morelec, Marc Janier, Francesco Giammarile; PK/PD specialists: Michel Tod, Marie-Claude Gagnieu, Sylvain Goutelle; Clinical Research Assistant: Eugénie Mabrut.

Contributors CRO wrote the first draft of the manuscript. SL, CD and TF participated in the patient care and made adequate changes to the manuscript.

Competing interests None declared.

Patient consent Not obtained.

Provenance and peer review Not commissioned; externally peer reviewed.

\section{REFERENCES}

1 Proctor RA, von Eiff C, Kahl BC, et al. Small colony variants: a pathogenic form of bacteria that facilitates persistent and recurrent infections. Nat Rev Microbiol 2006:4:295-305.

2 Tande AJ, Osmon DR, Greenwood-Quaintance KE, et al. Clinical characteristics and outcomes of prosthetic joint infection caused by small colony variant staphylococci. MBio 2014;5:e01910-14.

3 Sendi P, Frei R, Maurer TB, et al. Escherichia coli variants in periprosthetic joint infection: diagnostic challenges with sessile bacteria and sonication. J Clin Microbiol 2010;48:1720-5

Copyright 2017 BMJ Publishing Group. All rights reserved. For permission to reuse any of this content visit http://group.bmj.com/group/rights-licensing/permissions.

BMJ Case Report Fellows may re-use this article for personal use and teaching without any further permission.

Become a Fellow of BMJ Case Reports today and you can:

- Submit as many cases as you like

- Enjoy fast sympathetic peer review and rapid publication of accepted articles

- Access all the published articles

- Re-use any of the published material for personal use and teaching without further permission

For information on Institutional Fellowships contact consortiasales@bmjgroup.com

Visit casereports.bmj.com for more articles like this and to become a Fellow 